The Agriculturists 13(1): 140-151(2015) ISSN 2304-7321 (Online), ISSN 1729-5211 (Print)

\title{
Factors Affecting Adoption of Improved Sesame Technologies in Some Selected Areas in Bangladesh: An Empirical Study
}

\author{
M. A. Monayem Miah*, Sadia Afroz, M. A. Rashid and S. A. M. Shiblee \\ Agricultural Economics Division, Bangladesh Agricultural Research Institute (BARI), Joydebpur, \\ Gazipur-1701, Bangladesh \\ *Corresponding author and Email: monayem09@yahoo.com
}

Received: 15 July 2014

Accepted: 06 June 2015

\begin{abstract}
This study was undertaken to assess the adoption level as well as farmers' attitude towards cultivating Bangladesh Agricultural Research Institute (BARI) developed improved sesame varieties and its technology management as well. Keeping this view in mind, primary data were collected from major three sesame growing areas of Bangladesh namely, Comilla, Jessore, and Faridpur districts. A total of 540 samples, selected using stratified random sampling method, were interviewed using pre-tested and structured questionnaires. Results reveal that the improved sesame seed adoption level is around one fifth of the total sesame cultivation. The adoption of relating technologies regarding input usage and agronomic practices also depicted similar characteristics due to not taking up recommended improved seed package. Analysis also showed that availability of family labor, application of improved seeds and monitoring and supervision of extension personnel's have significant contribution on improved seed adoption levels. Although farmers opined that they would be adopting the improved sesame seeds in the upcoming fostering season in view of expanding yields, profits, labor productivity and efficient cultivation. However, many farmers have articulated their concern about unavailability of improved sesame seeds at the farm levels is a major barrier about adopting improved sesame technology.
\end{abstract}

Keywords: Sesame, adoption, improved seed, management technology

\section{Introduction}

Sesame (Sesamum indicum), a flowering plant in the genus Sesamum, is considered one of the oldest oilseed crops, domesticating well over 3000 years ago. History evidences that thousands of years ago, in the Middle East, indigenous residents discovered the use and benefits of sesame oil, making it a major summer crop ever since. It is widely naturalized in tropical regions around the world and is cultivated for its edible seeds, which grow in pods. It is also a robust crop that can be grown in various abiotic stress
conditions(http://en.wikipedia.org/wiki/Sesame\# Origins). In Bangladesh, sesame is an important summer oilseed crop occupying $9.4 \%$ of the total oilseed area (BBS, 2012). Sesame is highly beneficial as it contains $42-50 \%$ oil and the oil contains $42 \%$ essential linoleic acid, $25 \%$ protein and $16-18 \%$ carbohydrate. Moreover, premium quality edible and medicinal oil can be extracted from sesame, which can be conserved for a long time. Sesame oilcake is good feed for poultry, fish, cattle, goat and sheep (Khan et al., 2009). Unfortunately, the major obstacle to sesame expansion is low seed yield which results due to 
lack of non-shattering, water logged, and disease $\&$ insect resistant variety. The Oilseed Research Centre of Bangladesh Agricultural Research Institute (BARI) has released four improved varieties of sesame, of which the first variety was Til-6 which was released in 1976. All these varieties are late in maturity and very much susceptible to excess water.

Due to high competition among different high valued crops over the years, the acreage and production of sesame have dramatically decreased. More precisely, the area under sesame cultivation was 90.82 thousand hectares in 1989, whereas it decreased to 35.67 thousand hectares in 2012 (Miah et al., 2014). In 2012, the sesame cultivating area was 33.20 thousand hectares and the production was 30 thousand tons (BBS, 2012).

Adoption information on improved sesame varieties is very sporadic. Raikwar and Srivastva (2013) conducted a study on productivity enhancement of sesame through improved production technologies in Madhya Pradesh, India. The study revealed that the improved sesame variety produced a mean yield of 5.34 $\mathrm{q} /$ ha which was $34 \%$ higher than farmers practice yield of $3.45 \mathrm{q} / \mathrm{ha}$. The improved variety resulted higher mean net income of Rs.12914/ha as compared to local practice (7740/ha). With the financial and technical support of the Krishi Gobeshona Foundation (KGF), Akbar (2011) conducted a study at Manikgonj and Faridpur district on the adoption of modern rapeseed and sesame varieties with improved production technology for minimizing yield gap The study revealed that improved variety BINA Til-1 produced $83 \%$ higher yield $(1456 \mathrm{~kg} / \mathrm{ha})$, while BARI Til-3 produced 56\% higher yield (1244 $\mathrm{kg} / \mathrm{ha})$ compared to local check $(793 \mathrm{~kg} / \mathrm{ha})$. Again, BARI Til-4 produced the yield of 1536 $\mathrm{kg} / \mathrm{ha}$ which appeared to be as $93 \%$ higher in yield compared to check variety. Salam et al. (2011) assessed the status of adoption and estimated the profitability of sesame production in Jessore and Kushtia districts. Agronomic practices like method of land preparation, time of seed sowing, disease and pest control measures were highly adopted at farm level. The estimated net returns of Tk. 13947 and Tk.6211 per hectare was for improved and local variety respectively.

So, it is clear from the above discussion that indepth studies on improved sesame adoption are quite absent in the past. The adoption of improved sesame technologies at farm level is very essential as it will benefit our farmers in receiving higher yield and income. Policy makers, extension personnel, NGOs, and concerned scientists of our country can formulate appropriate policy using up-to-date adoption information for developing the crop throughout the country which will later be beneficial to the sesame farmers. Therefore, the present study was undertaken to:

i. study the adoption status of improved sesame varieties and their production technologies at farm level;

ii. find out the factors affecting the adoption of improved sesame technologies at farm level; and

iii. know farmers' experience with and attitudes toward improved sesame cultivation.

\section{Materials and Methods}

\subsection{Sampling technique}

A multi-stage sampling procedure was followed to select sample farmers. In the first stage, three major sesame growing districts namely Comilla, Jessore and Faridpur were selected for the study. Again, three highest sesame growing Upazilas from each district were selected in consultation with the Agricultural Officers of the respective Upazilas for conducting farm survey. A total of 540 (3 districts $\times 3$ Upazilas $\times 60 \mathrm{HHs}$ ) sesame cultivating farmers were randomly selected and interviewed for collecting field level data and socioeconomic information for the study.

\subsection{Analytical techniques}

For assessing the adoption of crop management technologies, respondent farmers were grouped 
into three categories such as high, medium, and low adopter based on the percentage of farmers who followed recommended practices with respect to each technology. A higher percentage indicates a higher level of adoption, while a lower percentage indicates a lower level of adoption of a technology. Adoption levels were categorized as (70-100\%) as high, (50-69\%) as medium, and $<50 \%$ as low; which was followed by different researchers (Islam et al., 2013; Salam et al., 2011; Miah et al., 2010; Akter et al., 2010).

Probit and Logit models have been extensively used by agricultural production and farming systems economists for studying and analyzing farmers' adoption and diffusion of agricultural interventions since long. Probit model is based on a cumulative normal distribution function which is symmetric around zero with variance equal to 1 (one). In Pakistan, Malik et al. (1991) used Probit analysis to examine the role of credit in agricultural development and Heisey et al. (1990) used this to identify the determinants of farmer awareness and adoption of wheat varieties. Traxler and Byerlee (1992) also used this analysis to identify the characteristics of insecticide farmers. Present study also used Probit regression model to find out the factors influence to adopt improved sesame variety.

The dependent variable of this model was adoption of improved varieties. It is known that the dependent variable is dichotomous so, Ordinary Least Square (OLS) couldn't be used. Therefore, MLE method was followed to run the Probit model using STATA software. The empirical probit model was:

$$
\begin{aligned}
& \mathrm{A}_{\mathrm{i}}=\alpha+\beta_{1} \mathrm{X}_{1}++\beta_{2} \mathrm{X}_{2}+\beta_{3} \mathrm{X}_{3}+\beta_{4} \mathrm{X}_{4}+\beta_{5} \mathrm{X}_{5}+ \\
& \beta_{6} \mathrm{X}_{6}+\beta_{7} \mathrm{X}_{7}+\beta_{8} \mathrm{X}_{8}+\ldots \ldots \ldots+\mathrm{U}_{\mathrm{i}}
\end{aligned}
$$

Where,

$\mathrm{A}_{\mathrm{i}}=$ Farmers adoption level of improved sesame variety (If adopted $=1$; Otherwise $=0$ )

$\alpha=$ Intercept

$\beta_{\mathrm{i}}=$ Coefficients of the respective variables $(\mathrm{i}=$ $1,2,3$---8)
$\mathrm{X}_{1}=$ Farm size (decimal)

$\mathrm{X}_{2}=$ Family labour (No./ha)

$\mathrm{X}_{3}=$ Education (Year of schooling)

$\mathrm{X}_{4}=$ Training on agriculture (No./life time)

$\mathrm{X}_{5}=$ Training on oilseed (No./life time)

$\mathrm{X}_{6}=$ Availability of improved seed (Score)

$\mathrm{X}_{7}=$ Cosmopolites of the farmer (Score)

$\mathrm{X}_{8}=$ Extension contact (Score)

$\mathrm{Ui}=$ Error term

\subsection{Variables used in the model and their measurement}

In estimating probit model, 'Adoption' was the dependent variable. This adoption was scored 1 (one) if farmers adopted improved sesame varieties, and 0 if they used indigenous sesame variety. The procedures of measuring independent variables included in the Probit model are briefly discussed below.

The independent variables are briefly defined below, while the descriptive statistics of those variables can be seen in Appendix-1.

Farm size: Farm land size is expected to affect the adoption of new technology positively (Miah et al., 2014)). Therefore, under subsistence agriculture, holding size (in decimal) is expected to play a significant role in influencing the adoption of improved sesame varieties at farm level.

Family labour: It was observed that the households with more farm labourers adopted improved sesame variety higher than the households having less farm labourers. Therefore, number of family labour (in manday/ha) was considered as an independent variable in the model. In the study areas, respondent households have used only adult male labourer.

Education: The higher level of education increases the skills, understanding and outlook of a person. Therefore, education (year of schooling) was expected that higher levels of education help farmers to adopt improved sesame technologies at farm level. 
Training: Farmer's training on crop production is important because it usually improves their technical skills on crop production practices and related aspects. Due to lack of training facilities, many farmers cannot harvest good profit through cultivating high-value crops. Therefore, it was expected that the adoption of improved sesame varieties would be influenced by training.

Availability of improved seed: The studied sesames cultivators collected or bought improved seeds from different sources. The availability of improved sesame seeds was assigned different values ranging from 0 to 4 (0 $=$ not available, $4=$ plenty) and these values were considered as score.

Cosmopoliteness: This variable was measured based on the frequency of the respondent's visit to different places outside his own village. Different values ( 0 for no visit and 3 for frequent visit) were assigned, based on frequency, for different places of visit. The actual score was then calculated by adding all the values. Possible scores ranged from 0 to 9 .

Extension contact: Farmers with good extension linkage used to have more responsive to up-todate information regarding modern agricultural technologies than that of non-linkage farmers. Therefore, extension linkage is supposed to have a positive effect on adoption of improved sesame technologies at farm level. The respondents were asked to mention the nature of contacts they had with different individuals and extension Medias. Ten different extension Medias were considered in this study. All these Medias were assigned different values ( 0 for no contact and 4 for regular contact) according to their importance. The actual score was measured by adding all the values (Appendix 2). The possible scores for extension contact were ranged from 0 to 40 .

\section{Results and Discussion}

\subsection{Adoption of improved sesame varieties}

Since 1976, BARI has developed four sesame varieties. Til-6 is one of them which is currently known as local variety among sesame farmers. The adoption of improved sesame varieties was found to be very low at farm level. Evidenced also shows that this improved variety is highly intensive in sesame growing areas in Comilla (Miah et al., 2014). Results revealed that about $21.5 \%$ of sesame farmers adopted improved varieties (BARI Sesame $3 \& 4$ ) and the rest $78.5 \%$ of them adopted BARI old sesame variety (Til-6) ${ }^{1}$ and other local varieties (Table 1). It was reported that Cereal System Initiative for South Asia (CSISA) project played an important role in disseminating improved sesame varieties in the study areas although most of the sesame farmers in the study areas still do not know about BARI developed improved varieties.

Department of Agricultural Extension (DAE) statistics show that sesame is being cultivated in 46 districts of Bangladesh. The scenario of sesame area covered by different varieties for three years (2008 to 2011) also presents a depressing picture in Bangladesh (Table 2). Currently, a vast sesame cultivated areas are covered by BARI old variety (Til-6) and other local varieties. Table 2 reveals that in 2010 2011 about $11.2 \%$ area were planted improved sesame varieties, which was comparatively less than that in 2009-2010 but it was higher than the area planted in 2008-2009. Therefore, the pictorial evidence of area coverage implies the importance of strengthening current variety adoption efforts in Bangladesh.

\subsection{Technology used in sesame cultivation}

The existing technology adoption level in the sesame production is presented in Table 3 . The sesame farmers ploughed their lands using power tiller of which, $46 \%$ farmers have followed the recommended ploughing techniques. The broadcast method for sowing sesame seeds was recommended to initiate from mid January to

\footnotetext{
${ }^{1}$ Sesame variety released by BARI before 2001 is treated as BARI old sesame variety. Only one sesame variety was released before 2001. T-6 is the most prominent and extensively cultivated old variety of sesame.
} 
mid April, which was followed by majority farmers $(96.5 \%)$. The recommended sesame seed rate is 7 to $7.5 \mathrm{~kg} / \mathrm{ha}$, but most of the farmers used either more or less amounts of seed than that of recommendation. Majority of the sample farmers $(61.5 \%)$ did not irrigate their crop, but most of them (96.9\%) weeded their crop. Like irrigation, $62 \%$ of sesame farmers did not use any pesticide to control insects. In summary, it can be said that the level of adopting sowing time and method was significant, whereas the level of recommended technology of land preparation, seed rate application, irrigation and weeding was much lower. Table 4 reveals that sesame farmers often do not follow recommendations for applying fertilizers. Most of them applied less amounts of Urea and Triple Super Phosphate (TSP) than its recommended dosages. In case of Murate of Potash (MoP) application, more than $29 \%$ of farmers used higher amounts compare to the recommendations. Furthermore, majority of the sesame farmers did not apply gypsum and DAP fertilizers.

Table 1. Percent of adoption of different sesame varieties at household level

\begin{tabular}{lcccc}
\hline Variety & $\begin{array}{c}\text { Comilla } \\
(n=180)\end{array}$ & $\begin{array}{c}\text { Faridpur } \\
(n=180)\end{array}$ & Jessore $(n=180)$ & $\begin{array}{c}\text { All area } \\
(n=540)\end{array}$ \\
\hline A. Improved & $18.9(34)$ & $5.5(10)$ & $40.0(72)$ & $21.5(116)$ \\
BARI Sesame-3 & $18.9(34)$ & -- & $29.4(53)$ & $16.1(87)$ \\
BARI Sesame-4 & -- & $5.5(10)$ & & $1.9(10)$ \\
BINA Sesame-1 & -- & -- & $10.6(19)$ & $3.5(19)$ \\
B. BARI old variety & & & & \\
$\quad$ Til-6 & $48.9(88)$ & $41.7(75)$ & $50.6(91)$ & $47.0(254)$ \\
C. Local & $32.2(58)$ & $52.8(95)$ & $9.4(17)$ & $31.5(170)$ \\
\hline All variety & $100(180)$ & $100(180)$ & $100(180)$ & $100(540)$ \\
\hline
\end{tabular}

Note: Figures in the parentheses are respondent farmers

Table 2. Area under different sesame varieties at national level (46 districts)

\begin{tabular}{lcccccc}
\hline Variety & \multicolumn{2}{c}{$2010-2011$} & \multicolumn{2}{c}{$2009-2010$} & \multicolumn{2}{c}{$2008-2009$} \\
\cline { 2 - 6 } & Area (ha) & $\%$ & Area (ha) & $\%$ & Area (ha) & $\%$ \\
\hline A. BARI improved & 5,686 & 11.2 & 6,460 & 12.5 & 3,019 & 6.4 \\
BARI Sesame-2 & 2,063 & 4.1 & 2,198 & 4.3 & 1,663 & 3.5 \\
BARI Sesame-3 & 3,363 & 6.6 & 4,129 & 8.0 & 1,299 & 2.8 \\
$\quad$ BARI Sesame-4 & 260 & 0.5 & 133 & 0.3 & 57 & 0.1 \\
B. BARI old variety & & & & & & \\
$\quad$ Til-6 & 37,932 & 75.1 & 36,544 & 70.9 & 36,263 & 77.1 \\
C. Local variety & & & & & & \\
\hline All variety & 50,522 & 100 & 51,551 & 100 & 47,019 & 100 \\
\hline
\end{tabular}

Source: Author's calculation from data collected from district level DAE Office, 2012 
Table 3. Percent of adoption of crop management technologies used in sesame cultivation

\begin{tabular}{|c|c|c|c|c|c|}
\hline Technology & $\begin{array}{l}\text { Jessore } \\
(n=180)\end{array}$ & $\begin{array}{l}\text { Faridpur } \\
(n=180)\end{array}$ & $\begin{array}{l}\text { Comilla } \\
(n=180)\end{array}$ & $\begin{array}{l}\text { All area } \\
(n=540)\end{array}$ & $\begin{array}{l}\text { Adoption } \\
\text { level }\end{array}$ \\
\hline \multicolumn{6}{|l|}{ Plowing and laddering } \\
\hline Recommended (4-5) & $11.5(62)$ & $12.4(67)$ & $22.0(119)$ & $46.0(248)$ & \multirow[t]{3}{*}{ Low } \\
\hline Below recommendation (1-3) & $65.6(118)$ & $61.7(111)$ & $32.8(59)$ & $53.3(288)$ & \\
\hline Above recommendation $(>5)$ & -- & $1.1(2)$ & $1.1(2)$ & $0.7(4)$ & \\
\hline \multicolumn{6}{|l|}{ Seed sowing time } \\
\hline *Mid February-mid April & $91.7(165)$ & $98.3(177)$ & $100(180)$ & $96.5(521)$ & \multirow[t]{2}{*}{ High } \\
\hline Before recommendation & $8.3(15)$ & $1.7(3)$ & -- & $3.5(19)$ & \\
\hline \multicolumn{6}{|l|}{ Seed sowing method } \\
\hline Line sowing & -- & -- & -- & -- & \multirow[b]{2}{*}{ High } \\
\hline *Broadcasting & $100(180)$ & $100(180)$ & $100(180)$ & $100(540)$ & \\
\hline \multicolumn{6}{|l|}{ Seed rate $(\mathrm{kg} / \mathrm{ha})$} \\
\hline Recommended (7-7.5) & $38.9(70)$ & $26.7(48)$ & $16.7(30)$ & $27.4(148)$ & \multirow[t]{3}{*}{ Low } \\
\hline Below recommendation & $45.6(82)$ & $55.6(100)$ & $11.1(20)$ & $37.4(202)$ & \\
\hline Above recommendation & $15.6(28)$ & $17.8(32)$ & $72.2(130)$ & $35.2(190)$ & \\
\hline \multicolumn{6}{|l|}{ Irrigation provide } \\
\hline Recommended (2 times) & $5.0(9)$ & $8.3(15)$ & $32.2(58)$ & $15.2(82)$ & \multirow[t]{4}{*}{ Low } \\
\hline Below recommendation & $10.0(18)$ & $18.3(33)$ & $36.7(66)$ & $21.7(117)$ & \\
\hline Above recommendation & $0.6(1)$ & $0.6(1)$ & $1.7(3)$ & $0.9(5)$ & \\
\hline Not provided & $84.4(152)$ & $72.8(131)$ & $29.4(53)$ & $62.2(336)$ & \\
\hline \multicolumn{6}{|l|}{ Weeding } \\
\hline Recommended (2 times) & $61.1(110)$ & $15.0(27)$ & $51.7(93)$ & $42.6(230)$ & \multirow[t]{4}{*}{ Low } \\
\hline Below recommendation & $11.7(21)$ & $75.0(135)$ & $43.9(79)$ & $43.5(235)$ & \\
\hline Above recommendation & $27.2(49)$ & $1.7(3)$ & $3.3(6)$ & $10.7(58)$ & \\
\hline Not weeded & -- & $8.3(15)$ & $1.1(2)$ & $3.1(17)$ & \\
\hline \multicolumn{6}{|l|}{ Insect-pest control } \\
\hline Do not use pesticides & $61.7(111)$ & $91.1(164)$ & $33.3(60)$ & $62.0(335)$ & \multirow[t]{2}{*}{--} \\
\hline Used pesticides & $38.3(69)$ & $8.9(16)$ & $66.7(120)$ & $38.0(205)$ & \\
\hline
\end{tabular}

Note: Figures in the parentheses indicate no. of respondents

*Recommendation; Adoption level: $70-100 \%$ as high; $50-69 \%$ as medium; and $<50 \%$ as low.

\subsection{Determinants of adoption of improved sesame varieties}

The adoption of improved sesame varieties was likely to be influenced by different socioeconomic factors. Study results presented in Table 5 also depicts that the estimated coefficients of the availability of family labour, availability of improved seed, cosmopolitness of the farmer, and contract with different extension sources implies that these variables had positive and significant impacts on the adoption of improved sesame varieties in the study areas. The positive and significant coefficients of these variables imply that if these factors were to be increased by $100 \%$, the probability of adopting improved sesame varieties would be increased by $0.01,2.52,0.63$, and $0.09 \%$, respectively (Table 6). 
Table 4. Percent of farmers used manure and fertilizer in sesame cultivation

\begin{tabular}{|c|c|c|c|c|c|}
\hline Particular & $\begin{array}{l}\text { Jessore } \\
(n=180)\end{array}$ & $\begin{array}{l}\text { Faridpur } \\
(n=180)\end{array}$ & $\begin{array}{l}\text { Comilla } \\
(n=180)\end{array}$ & $\begin{array}{l}\text { All area } \\
(n=540)\end{array}$ & $\begin{array}{c}\text { Adoption } \\
\text { level }\end{array}$ \\
\hline \multicolumn{6}{|l|}{ *Cowdung } \\
\hline Applied & $36.7(66)$ & $2.2(4)$ & $10.6(19)$ & $16.5(89)$ & \\
\hline Not applied & $63.3(114)$ & $97.8(176)$ & $89.4(161)$ & $83.5(451)$ & \\
\hline \multicolumn{6}{|l|}{$\operatorname{Urea}(\mathbf{k g} / \mathbf{h a})$} \\
\hline Recommended (100-150) & $22.8(41)$ & $5.6(10)$ & $20.0(36)$ & $16.1(87)$ & Low \\
\hline Below recommendation & $63.3(114)$ & $40.0(72)$ & $58.3(105)$ & $53.9(291)$ & \\
\hline Above recommendation & $4.4(8)$ & $0.6(1)$ & $12.2(22)$ & $5.7(31)$ & \\
\hline Non-users & 9.4 (17) & $53.9(97)$ & $9.4(17)$ & $24.3(131)$ & \\
\hline \multicolumn{6}{|l|}{ TSP (kg/ha) } \\
\hline Recommended (130-150) & $9.4(17)$ & $2.2(4)$ & $2.8(5)$ & $4.8(26)$ & Low \\
\hline Below recommendation & $71.1(128)$ & $30.0(54)$ & $47.8(86)$ & $49.6(268)$ & \\
\hline Above recommendation & $4.4(8)$ & $0.6(1)$ & $6.1(11)$ & $3.7(20)$ & \\
\hline Non-users & $15.0(27)$ & $67.2(121)$ & $43.3(78)$ & $41.9(226)$ & \\
\hline \multicolumn{6}{|l|}{ MoP (kg/ha) } \\
\hline Recommended (40-50) & $11.7(21)$ & $3.3(6)$ & $5.6(10)$ & $6.9(37)$ & Low \\
\hline Below recommendation & $12.8(23)$ & $10.6(19)$ & $4.4(8)$ & $9.3(50)$ & \\
\hline Above recommendation & $48.9(88)$ & $11.1(20)$ & $27.2(49)$ & $29.1(157)$ & \\
\hline Non-users & $26.7(48)$ & $75.0(135)$ & $62.8(113)$ & $54.8(296)$ & \\
\hline \multicolumn{6}{|l|}{ Gypsum (kg/ha) } \\
\hline Recommended (100-110) & -- & -- & -- & -- & Low \\
\hline Below recommendation & $12.2(22)$ & $0.6(1)$ & $11.1(20)$ & $8.0(43)$ & \\
\hline Non-users & $87.8(158)$ & $99.4(179)$ & $88.9(160)$ & $92.0(497)$ & \\
\hline \multicolumn{6}{|l|}{$* \mathbf{D A P}$} \\
\hline Applied & $2.2(4)$ & $12.8(23)$ & $0.6(1)$ & $5.2(28)$ & -- \\
\hline Not applied & $97.8(176)$ & $87.2(157)$ & $99.4(179)$ & $58.3(315)$ & \\
\hline
\end{tabular}

Note: Figures in the parentheses indicate no. of respondents

*No recommendation; Adoption level: $70-100 \%$ as high; $50-69 \%$ as medium; and $<50 \%$ as low.

Table 5. Maximum likelihood estimates of probit model

\begin{tabular}{lllcc}
\hline Explanatory variable & Coefficients & Standard Error & z-statistic & Probability \\
\hline Constant & $-14.77490^{* * *}$ & 2.521081 & -5.86 & 0.000 \\
Farm size (No./ha) & 0.00008 & 0.000610 & 0.14 & 0.892 \\
Family labor (No./family) & $0.02023^{* *}$ & 0.009209 & 2.20 & 0.028 \\
Education (Year of schooling) & 0.03110 & 0.036791 & 0.85 & 0.398 \\
Training on agriculture (No./life time) & 0.09891 & 0.121648 & 0.81 & 0.416 \\
Training on oilseed (No./life time) & 0.35446 & 0.660211 & 0.54 & 0.591 \\
Availability of improved seed (Score) & $4.87835^{* * *}$ & 0.932545 & 5.23 & 0.000 \\
Cosmopolitness (wt. score) & $1.22388^{* * *}$ & 0.253079 & 4.84 & 0.000 \\
Extension contract (wt. score) & $0.16748^{* * *}$ & 0.057145 & 2.93 & 0.003 \\
\hline
\end{tabular}

Note: Dependent variable $=$ Improve variety adoption $($ Adopter $=1$, Non-adopter $=0)$

No. of observation $=540 ;$ LR chi-square $(8)=446.05 ;$ Log likelihood $=-57.920995$;

'***' and '**' represent significant at $1 \%$ and $5 \%$ level respectively 
Table 6. Marginal effect of the variables determining adoption of improved sesame varieties

\begin{tabular}{llccc}
\hline Explanatory variable & dy/dx & $\begin{array}{l}\text { Standard } \\
\text { Error }\end{array}$ & z-statistic & Probability \\
\hline Farm size (No./ha) & 0.0000428 & 0.00000 & 0.14 & 0.892 \\
Family labor (No./family) & $0.0001046^{* * *}$ & 0.00015 & 2.20 & 0.028 \\
Education (Year of schooling) & 0.0001607 & 0.00026 & 0.85 & 0.398 \\
Training on agriculture (No./life & 0.0005112 & 0.00082 & 0.81 & 0.416 \\
time) & & & & \\
Training on oilseed (No./life time) & 0.0018319 & 0.00431 & 0.54 & 0.591 \\
Availability of improved seed (Score) & $0.0252113^{* * *}$ & 0.03182 & 5.23 & 0.000 \\
Cosmopolitness (Score) & $0.0063250^{* * *}$ & 0.00821 & 4.84 & 0.000 \\
Extension contract (Score) & $0.0008655^{* * *}$ & 0.00123 & 2.93 & 0.003 \\
\hline
\end{tabular}

Note: ' $* * *$ ' and ' $* *$ ' represent significant at $1 \%$ and $5 \%$ level respectively

Table 7. Willingness of farmers to increase sesame cultivation in the next year

\begin{tabular}{lccc} 
& & & (Figures in \%) \\
\hline Particulars & Adaptor $(n=116)$ & Non adapter $(n=424)$ & All category $(n=540)$ \\
\hline 1. Increase & 77.59 & 80.90 & 80.19 \\
2. Not increase & 17.24 & 14.62 & 15.19 \\
3. Decrease & 5.17 & 4.48 & 4.63 \\
\hline
\end{tabular}

\subsection{Farmers' attitudes toward sesame cultivation}

The respondent farmers were asked to mention the possibility of expanding their improved sesame cultivated area. Results show that amongst the sesame cultivators, $77.59 \%$ showed their interest to increase improved sesame cultivation areas in the coming year. While, amongst the non-adopters, $80.90 \%$ showed interest to expand their cultivable areas. About $17.24 \%$ of adopting and $15.19 \%$ of non-adopting sesame farmers did not show their interest of expanding sesame cultivation area in near future (Table 7).

Study also analysis the reason of farmers' willingness of expanding the adopting improved sesame varieties. Results reveal that more than 77\%farmers opined that this improve sesame varieties will produce higher yield as well higher prices. Besides, lowered cultivation costs and sustainable higher profits that can be attained through the instigation of improved sesame cultivation technology also the important reasons of cultivating improved sesame variety; which requires less oilseed cultivable land and labor, ultimately easing the cultivation process (Table 8).

Some adopting and non-adopting sesame farmers mentioned various reasons for not expanding their sesame area in coming years. Of them the most important reasons were scarcity of cultivable land as they need to grow other crops. A very small percentage of respondents also mentioned that higher cost of production is a barrier to expand sesame cultivation in the next year. About $1.7 \%$ of sesame farmers mentioned that sesame cultivation is less profitable compared to maize, onion, carrot and vegetables. Some farmers did not want to increase sesame cultivation because it hampers Boro rice cultivation and lack of short duration improved variety seed (Table 8). 
Table 8. Reasons for increasing sesame cultivation in the near future

\begin{tabular}{lc}
\hline \multicolumn{1}{c}{ Reasons } & Responses (\%) \\
\hline A. Reasons for increasing & 77.4 \\
1. Higher yield and good product price & 18.5 \\
2. Low cost, but high profit & 30.9 \\
3. Easy cultivation and needs less labour & 4.4 \\
4. Availability of cultivable land & \\
B. Reasons for not increasing & 8.1 \\
1. Scarcity of cultivable land & 1.7 \\
2. Less profitable compared to other crops & 3.1 \\
3. Higher cost of production & 0.4 \\
7. Others* & 2.2 \\
C. Reasons for decreasing & 2.2 \\
1. Scarcity of suitable cultivable land & 0.7 \\
2. Higher cost of production & \\
3. Less profitable compared to other crops & \\
\hline
\end{tabular}

*Delay in Boro rice production, lack of short duration variety seed, foggy weather, decrease soil fertility due to use same cropping pattern repeatedly, increase rice cultivation, and lack of irrigation facility.

A small number of adopting and non-adopting farmers also mentioned some reasons for decreasing their sesame area for the next year. They claimed that there existed scarcity of suitable cultivable land as they need to grow other crops and that sesame cultivation led to higher costs of production, comparatively lower profits to other crops, and lack of irrigation facility (Table 8).

\subsection{Facility needed for increasing sesame cultivation}

Many respondent farmers suggested that some facilities need to be created for them in order to expand their oilseed area in the near future. All of their demands are presented in Table 9.

The availability of cultivable land is a significant element for growing or expanding area for sesame. About $6.5 \%$ of sesame farmers liked to expand their cultivation for the next year if they could manage additional cultivable land on lease or mortgages. Short duration improved oilseed varieties are pre-requisites for expanding sesame cultivation throughout the study area. Also, many farmers demanded short duration T.Aman rice variety (BINA Dhan-7) so that they can harvest $T$. Aman rice early and cultivate sesame in between T. Aman and Boro rice cultivation. A good number of sesame growing farmers in the study areas mentioned the need for short duration improved oilseed varieties. As good quality seeds, fertilizers and pesticides are vital inputs in the procurement process of profitable sesame production, inputs should be available to the farmers at lower prices. More than $4 \%$ of farmers requested that the government should reduce the existing input prices. As farmers require liquid money at the time of cultivation, institutional credit facilities should be made available at the proposed time period to enable farmers to increase the volume of production. Several farmers wanted easy access to institutional credit facilities consisting of feasible and lenient terms and conditions in conjunction to the overpowering, high interest rates on noninstitutional credit. 
Table 9. Facilities demanded by the sesame farmers for increasing sesame cultivation

\begin{tabular}{lc}
\hline \multicolumn{1}{c}{ Facility } & \% responses \\
\hline 1. Availability of cultivable lands & 6.5 \\
2. Improved short duration varieties & 5.6 \\
3. Ensuring low price of inputs & 4.3 \\
4. Credit facility with easy terms & 3.1 \\
5. Adequate irrigation facility & 0.7 \\
6. Ensuring fair price of their produces & 0.9 \\
7. Hand-on training on oilseed cultivation & 3.5 \\
8. Reducing labour scarcity problem & 1.9 \\
9. Other facilities* & 2.8 \\
\hline * Short duration variety of $T$. Aman rice, cooperation from extension personnel, low cost of plough, removal of
\end{tabular}

Irrigation is an important input for crop production as it helps increase crop productivity to a great extent. Although, most of the study areas have irrigation facilities but, the crop production of sesame farmers are often hampered by the constraints of frequent load shedding of electricity. Nevertheless, some farmers are still distressed over the disparity of inadequate irrigation facilities. As a result, they demanded immediate reinforcement of the emphasized facilities in the study areas. Training is an important tool that enhances knowledge and skill of farmers. It is noted that a small percentage of sesame adopting and non-adopting farmers were approached to provide hands-on training regarding oilseed production. Farmers also proposed some other facilities such as strengthening extension personnels' cooperation, availability of crop threshing machine, low cost of plough, removal of water logging problem and suitable storage facility to expand improve sesame cultivation in the study areas.

\section{Conclusions and Recommendations}

The study has been conducted to assess the adoption level of improved sesame cultivation at the farm level. It can be concluded from the results that the levels of adoption of the improved sesame varieties along with their management technologies are very low in the study areas. Amongst the sesame cultivators, most of them used BARI old sesame varieties. The factors that significantly influenced farmers to adopt improved variety are family labour, availability of improved seed, farmers' cosmopolitness, and extension contract. Respondent sesame farmers face various problems during its cultivation such as lack of short duration seeds (sesame \& T.Aman), infestation of insects and diseases, lack of finance in terms of liquidity and credit sources, higher cultivation costs, inconsistent supply of electricity, insufficient training and knowledge facilities, water logging and storage capacity, magnified input prices, scarcity of cultivable land and unsuitable weather conditions. Farmers' perceptions on improved sesame cultivation reveal that most of the respondent farmers wanted to increase sesame cultivation in coming years considering the higher benefit of them in compare to the local variety cultivation.

For higher adoption of improved sesame seed and technology in Bangladesh, the Government may take following measures:

- Ensure the adequate supply of improved and short-duration sesame variety seeds at farmers' level.

- Provide hand-on training to the sesame farmers on improved sesame cultivation and crop management practices. 
- Existing extension services should be strengthened for higher adoption of sesame technologies.

- Ensure affordable price of the inputs and fair price of the output (sesame) for the farmers.

- Credit facilities with favourable terms and conditions should be extended to the enthusiastic sesame farmers.

\section{References}

Akbar, M. A. 2011. Adoption of modern rapeseed mustard and sesame varieties with production technology for yield gap reduction. Project No. 16. Agrarian Research Foundation (ARF), Dhaka.

Akter, M., Miah, M. A. M., Rahman, M. S. and Khurram, M. M. H. 2010. Adoption and relative profitability of groundnut (Arachis hypogaea L.) cultivation in char areas of Bangladesh. Bangladesh J. of Agri., 35 (1): 85-95.

BBS, 2012. Agricultural Statistics of Bangladesh, Bangladesh Bureau of Statistics, Ministry of Planning, Dhaka, Bangladesh.

Heisey, P., Tetlay, W., Ahmad, Z. and Ahmad, M. 1990. Varietal change in post-green revolution agriculture: empirical evidence for wheat in Pakistan. Journal of Agricultural Economics, 44(3): 428-442.

Islam, Q. M. S., Miah, M. A. M., Rahman, M. S. and Hossain, M. S. 2013. Adoption of BARI mung varieties and its constraints to higher production in southern region of Bangladesh. Bangladesh J. Agricultural Research, 38(1): 85-96.

Khan, M. A. H., Sultan, N. A., Islam, M. N. and Hasanuzzaman, M. 2009. Yield and yield contributing characters of sesame as affected by different management practices. American-Eurasian Journal of Scientific Research, 4(3): 195-197.

Malik, S. J., Mushtaq M. and Gill, M. A. 1991. The role of institutional credit in the agricultural development of Pakistan. The Pakistan Development Review, 30(4): 1039-1048.

Miah, M. A. M., Rashid M. A. and Shible, S. A. M. 2014. Assessment of socioeconomic impacts of oilseed research and development in Bangladesh. SPGR Subproject Completion Report, Bangladesh Agricultural Research Council (BARC), Farmgate, Dhaka-1215.

Miah, M. A. M., Akter, M., Khurram, M. M. M. H., Salam, M. A. and Uddin, M. A. 2010. Adoption of BARI mustard technology in selected areas of Bangladesh. Eco-friendly Agriculture Journal, 3(2): 123-130.

Raikwar, R. S. and Srivastva, P. 2013. Productivity enhancement of sesame (Sesamum indicum L.) through improved production technologies. African Journal of Agricultural Research, 8(47): 60736078.

Salam, M. A., Khurram, M. M. H., Moniruzzaman S. M and Hossain, S. 2011. The economics of sesame production in two selected areas of Bangladesh. Bangladesh Journal of Agriculture, 36 (1): 117-129.

Traxler, G. and Byerlee, D. 1992. Crop management research and extension: the products and their impact on productivity. CIMMYT Economics Paper No. 5. Mexico, D.F.: CIMMYT. 
Appendix 1. Descriptive statistics of the variables included in the probit model

\begin{tabular}{|c|c|c|c|c|c|c|c|c|}
\hline 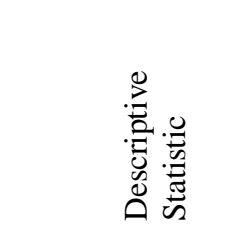 & 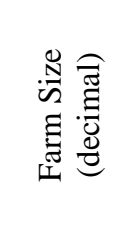 & 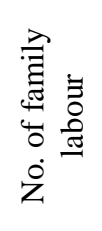 & 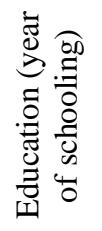 & 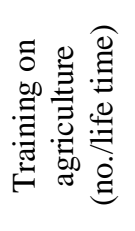 & 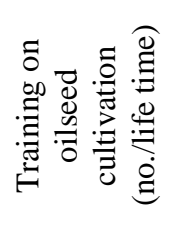 & 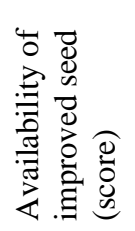 & 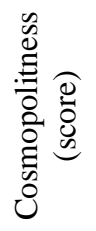 & 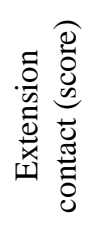 \\
\hline Mean & 255.6 & 42.9 & 5.0 & 0.9 & 0.1 & 0.5 & 5.7 & 6.9 \\
\hline Std. error & 10.6 & 0.7 & 0.2 & 0.1 & 0.0 & 0.0 & 0.0 & 0.2 \\
\hline Median & 190.0 & 43.0 & 5.0 & 0.0 & 0.0 & 0.0 & 6.0 & 6.0 \\
\hline Mode & 125.0 & 45.0 & 0.0 & 0.0 & 0.0 & 0.0 & 6.0 & 6.0 \\
\hline Std. deviation & 245.8 & 15.7 & 4.0 & 1.5 & 0.3 & 0.7 & 1.1 & 3.8 \\
\hline Sample variance & 60435 & 246.6 & 16.2 & 2.3 & 0.1 & 0.5 & 1.3 & 14.4 \\
\hline Kurtosis & 28.1 & 0.2 & -1.1 & 7.2 & 19.1 & -0.3 & 1.3 & 4.3 \\
\hline Skewness & 4.3 & 0.3 & 0.2 & 2.5 & 4.0 & 1.0 & -0.7 & 1.7 \\
\hline Range & 2614.0 & 90.4 & 15.0 & 10.0 & 3.0 & 2.0 & 7.0 & 28.0 \\
\hline Minimum & -156.0 & 4.1 & 0.0 & 0.0 & 0.0 & 0.0 & 2.0 & 0.0 \\
\hline Maximum & 2458.0 & 94.5 & 15.0 & 10.0 & 3.0 & 2.0 & 9.0 & 28.0 \\
\hline Sum & 138029 & 23170 & 2703 & 470 & 52 & 275 & 3095 & 3748 \\
\hline Count & 540 & 540 & 540 & 540 & 540 & 540 & 540 & 540 \\
\hline
\end{tabular}

Appendix 2. Calculation of the score of extension contact

\begin{tabular}{|c|c|c|c|c|c|}
\hline \multirow[t]{2}{*}{ Contact with extension Media } & \multicolumn{5}{|c|}{ Extent of contact } \\
\hline & $\begin{array}{l}\text { Regular } \\
\text { (4) }\end{array}$ & Frequently (3) & $\begin{array}{c}\text { Sometimes } \\
\text { (2) }\end{array}$ & Often (1) & Never $(0)$ \\
\hline 1. Extension personnel & - & 3 & - & - & - \\
\hline 2. Neighbouring farmers & 4 & - & - & - & - \\
\hline 3. Participate in agril. fair & - & - & - & 1 & - \\
\hline 4. Agril. programme in radio & - & - & 2 & - & - \\
\hline 5. Agril. programme in TV & - & 3 & - & - & - \\
\hline 6. Visit to block demonstration & - & - & - & 1 & - \\
\hline 7. Agril. book reading & - & - & 2 & - & - \\
\hline 8. Newspaper reading & 4 & - & - & - & - \\
\hline 10. Visit to research institutes & - & - & - & - & 0 \\
\hline
\end{tabular}

Total score of extension contact for a respondent $=(3+4+1+2+3+1+2+4+0)=20$ 